\title{
4 \\ The public purposes of the university: a historical view, 1995-2010
}

\author{
Lis Lange
}

\section{Introduction}

ince the 1950s the benefits of university education have been extended S to an ever larger number of people, with some countries achieving mass and universal higher education (Trow, 1973; Scott, 1995) while others still struggle to make access to higher education a reality (Altbach, 2009). On the eve of the 21st century the definition of universities as engines of development (Castells, 2001) led both the World Bank and the Organisation for Economic Co-operation and Development to revise their position on the role and purpose of universities in the developing world. Much has been researched and written about the roles of the university in delivering global competitiveness and innovation and in informing public policy and therefore supporting social change.

National policies and supranational frameworks have also identified the role of higher education in the life of democratic societies and specifically in the education of citizens (DoE, 1997; World Bank, 2001; Watson and Amoah, 2007). The declaration of the last UNESCO World Conference on Higher Education in 2009 unambiguously identified higher education as a public good precisely on the strengths of its role in the advancement of society. Interestingly, higher education has, at the same time, been regarded more and more as an allocator of individual opportunity, expected to deliver direct economic benefits to both society and the individual within a short-term frame (Boulton and Lucas, 2008:15-20). In many respects the public character of the university seems to be simultaneously stretched and narrowed, depending 
on the manner in which different national higher education systems relate to the state and a variety of other stakeholders and how these relations shape the core functions of higher education.

Against this background this chapter looks at the post-1994 stated purposes of public higher education in South Africa and argues that there is an identifiable sequence in the implementation of these purposes by the successive ANC governments. The chapter takes a closer look at the role of higher education in the development of citizenship and argues that of all the purposes and roles allocated to higher education, this has been the least foregrounded at the level of implementation due to its deep roots in teaching and learning. It is organised in three sections. The first section analyses the notion of the public university in South Africa as presented in both the policy texts and the reflections and interpretations of those texts in the context of implementation. The second section articulates a tentative sequence of the focus of policy implementation by looking at the circumstances that conditioned the privileging of some purposes over others. The third looks into the purpose of higher education which was least developed in the policy framework: the development of citizenship.

\section{Defining the purpose of public higher education in South Africa}

Unlike in other African countries, universities did not emerge in South Africa as a sign of the independence of the new country, nor as an instrument of the state in shaping postcolonial society. South African universities were either part of a settler society, performing a variety of social, economic and ideological functions in the colonial context (historically white universities) or they functioned as essential pieces for the reproduction of a system of racial domination (historically black universities) (Cloete et al, 2005; Sehoole, 2005; Mamdani, 2011). By the time of the inauguration of the first democratic government, South Africa did not have a higher education system but 36 public higher education institutions created by acts of government. Constituted of 21 universities and fifteen technikons - higher education institutions offering vocational education - in 1994 the institutions that comprised South Africa's higher education sector were divided along racial, ethnic, linguistic and geographical lines. Add to that their role in society and their varied relationship to the state and it is difficult to talk about a system of public universities. In fact, South Africa's very notion of the public was narrowly defined to fit a variety of socio-political and economic contexts in the overall architecture of apartheid, one of whose bases was restricted citizenship. One of the tasks of the new democratic government was to broaden the notions of 
public and citizenship in all spheres of life in the country. In higher education this needed to be accompanied by the creation of a single, coordinated and diverse higher education system. The difficulties encountered in the process of doing this - the political constraints, choices and compromises made by successive governments, as well as their role in shaping the current reality of the higher education system - have been discussed by several authors (Badat, 2008; CHE, 2004; Cloete and Moja, 2005; Sehoole, 2005).

South Africa's current higher education system was defined and constructed against the backdrop of apartheid; it had to support the concrete eradication of the legacy of apartheid within its institutions and in society itself. As transformation became the supra objective of all reform in the country, the term became the conceptual shorthand that defined the nature and direction of this change (Singh, 1992; Motala, 2005). As an indication of its ubiquity within higher education policy discourse, consider the title of the report from the presidentially appointed National Commission on Higher Education and the subtitle of the Higher Education White Paper (hereafter White Paper): $A$ framework for transformation and a programme for transformation. Despite their lack of legal status, the fact that both the National Commission report and the White Paper are among the most cited documents in higher education policy shows the role these documents played in influencing visions of higher education at both a system and institutional level.

To discuss the purposes of higher education, in this chapter I focus particularly on the White Paper. A close reading of the White Paper shows a conceptual architecture in which the purposes, principles, values and an overall vision for the higher education system are interlinked. Indeed one of the characteristics of the call for change in the document is the strong sense of urgency and simultaneity (DoE, 1997: Preface, 1.1. and 1.2.). The White Paper proposed four purposes for higher education, eventually assimilated into the Higher Education Act:

to meet the learning needs and aspirations of individuals through the development of their intellectual abilities and aptitudes throughout their lives

- to address the development needs of society and provide the labour market with appropriate high-level skills

to contribute to the socialisation of enlightened, responsible and constructively critical citizens

- to contribute to the creation, sharing and evaluation of knowledge (DoE, 1997:3:1.3). 
These purposes, shared by other higher education systems, were contextualised through the characterisation of South African higher education as unable to match the needs of a society in political, economic, social and moral transition (DoE, 1997:1.4). The definition of the principles informing the vision of a new higher education system - equity and redress, democratisation, development, quality, and effectiveness and efficiency - speak both to the specificity of the local problems and the challenges faced by all mass higher education systems.

The definition of higher education as simultaneously a private and a public good is subsumed in the conceptualisation presented in the White Paper. From the perspective of current discussion about this topic (Calhoum, 2006; Jonathan, 2001; Singh, 2001) it is important to note the extent to which the paper looks at individual redress (private benefit) from a social perspective. The narrowing of the distance between the private and the public in the process of transformation needs to be understood against apartheid's explicit subjugation of the individual as subject and agent and of the group as a social category. In this regard it is noteworthy that the White Paper not only refers to abolishing unjust differentiation, it also seeks to implement measures of empowerment for individuals and institutions (DoE, 1997:1.18). In other words, it was not enough to dismantle apartheid: apartheid had to be replaced with a system able to undo its effects.

The purposes of higher education itself had to be seen in the context of the needs for reconstruction and development. Higher education was regarded as both a condition and an agent for changing the social relations which characterised South Africa under apartheid, and this bedevilled the political choices that needed to be made at both government and institutional level in order to facilitate change. This task was not made easy by the competing and equally urgent national needs.

Moreover, from the point of view of policy implementation, the purposes of higher education were translated into twelve system- and six institutionallevel goals which spoke to the concrete actions that needed to be taken to bring the higher education system into line with its new purposes.

As Badat (2008) has pointed out, all these goals had to be achieved simultaneously and the tensions and paradoxes derived from the apparent contradictions between equity, redress and quality and equity and development had to be made explicit. Despite this, the political rhythm of higher education transformation had its own priorities and stages. 


\section{Sequencing the focus of change}

It could be argued that since 1994 the transformation of higher education has seen a sequence of priorities, punctuated by the national political juncture and the macro-economic policy of the government. At the same time, however, research on higher education illustrated the range and depth of the problems identified in the policy, which therefore refocused implementation. The impact of this research needs to be taken into account. The identification of new issues did not imply that new priorities replaced old ones. On the contrary, each new focus added another layer of complexity to the understanding of both the policy goals and their concrete implications.

The White Paper constituted symbolic policy (Cloete et al, 2005; Lange, 2005) aimed at a clear ideological break with the past. This was consistent with both the government approach and the expectations of society in the initial stages of political transition. As a new state bureaucracy was set up and government established (Sehoole, 2005:67-96), the first focus was on equity, redress and democratisation. The concept of cooperative governance, introduced by the National Commission on Higher Education (NCHE), was taken up in the White Paper and made its way into legislation that transformed both the structure and decision-making processes in higher education institutions as well as the legal relationship between institutions and government (Hall et al, 2002; Cloete and Moja, 2005).

Equity and redress constituted the other central focus during this period. Increasing the size of the higher education system and changing its demographic composition was the fundamental priority between 1997 and the early 2000s. Government reports, debates about the development of monitoring systems and performance indicators and the establishment of the Higher Education Management Information System (HEMIS) within the Department of Education were largely geared to measuring how the higher education system was performing in terms of these two values. The concern with individual equity, however, was far clearer and more constant than the attempt to address issues of institutional equity derived from the history of historically black universities under apartheid. The fact that targeted predictions made by the National Commission on Higher Education about the expansion of enrolments were not met made the focus on equity and redress all the more urgent. A fundamental development in relation to the focus on individual redress was the creation of the National Students Financial Aid Scheme (NSFAS), which has been operating with a growing budget since its establishment in 1996. 
The preoccupation with equity was not naïve, however. While the genuine increases in black student enrolments across the higher education system were seen as sign of progress, the hidden inequalities between men and women and the different racial groups in the distribution of the enrolment across disciplinary and professional fields warned government and higher education institutions that equity and redress would be a constant priority (CHE, 2004; 2009). Concern with equity and redress was not restricted to enrolments; it also included academic staff as well. While the demographic profile of students was changing rapidly, the change in the staff profile was much slower and, moreover, the country was facing a crisis in its attempts to replace the current generation of academics (CHE, 2004; 2009).

Efficiency and effectiveness, the second level of reform priorities for institutions and the government, were foregrounded around 2003 with the introduction of the new funding formula which came to support attempts to plan enrolments in relation to the academic profiles of institutions. According to the White Paper, effectiveness was the achievement of the desired outcomes and efficiency referred to the lack of duplication and waste. Special attention was paid to the revolving door syndrome that affected higher education and the performance of institutions in relation to their outputs. Institutions were graduating too few students: while most took inordinately long to complete their degrees, a very large proportion was abandoning their studies due to a combination of financial and academic reasons. Insufficient graduates were being produced in identified areas of need in the country, such as science, engineering and technology. Efficiency and effectiveness were also among the issues around which the logic of restructuring the higher education system through mergers and incorporation was built. The restructuring was the initiative of the National Working Group appointed by the Minister of Education (CHE, 2000; DoE, 2001a; DoE, 2001b; Bunting and Cloete, 2004a).

The third level of reform was the development of a national system of quality assurance by the Council on Higher Education's (CHE) Higher Education Quality Committee (HEQC). The concern with quality of provision became particularly intense with the roll-out of the HEQC's institutional audits from 2004. The thick conceptualisation of quality proposed by the HEQC incorporated the tensions between equity, redress and quality, and addressed whether higher education institutions were fit for purpose in their own right as well as in relation to national development priorities under the banner of transformation (HEQC, 2001). 
When a study based on the first throughput figures of the 2000 class was published in 2007 (Scott et al, 2007), concerns about equity and redress and effectiveness and efficiency were refocused into the specific problems of the core functions of teaching and learning, raising the alarm as to the limits of the system's achievement in terms of equity. Equity of access was not accompanied by equity of success. At the same time, another study on institutional culture and success - initiated by the Council on Higher Education in 2008 began to show that equity and redress figures, although seemingly encouraging, were in fact blurring unresolved problems, not only in relation to success but also with regards to conflicting race relations inside higher education institutions and the impact these had on students' experience of higher education (CHE, 2010). The first reports of the HEQC's institutional audits confirmed the existence of such problems and showed the extent to which these issues were also affecting relations among staff (Executive summary of audit reports 2004-2007 on www.che.ac.za).

The fourth level of reform - development - was introduced in the policy under the rubric of responsiveness and development. Responsiveness was defined as the ability of higher education to meet the needs of an increasingly technologically oriented economy, to deliver research, highly trained people and the knowledge to address national needs and to participate in the global economy. Development referred to the ability of the higher education system to contribute to the common good of society through the production, acquisition and application of knowledge, the building of human capacity and the provision of lifelong learning opportunities (DoE, 1997:1.13 and 1.20). These concepts entered higher education hand in hand with the skills debate in the country and were formulated in terms of the inability of higher education to produce the number, type and quality of required graduates (Kraak et $a l$, 2003). Although the production of appropriate high-level skills was unequivocally included in the higher education policy framework, the urgency in relation to skills development came through national initiatives driven by the presidency. ${ }^{1}$

This sequence of priorities does not mean these were the only preoccupations concerning higher education during this period. The restructuring of the system of public higher education through mergers and incorporations brought to the fore a variety of specific issues about funding, infrastructure, capacity, administration, programme offerings and the overall fitness for purpose of institutions. In many respects these issues represent institutional variations on the national policy objectives. 
From the beginning of higher education reform the need to measure progress and change in the system concentrated the minds of the Department of Education, the Council on Higher Education and research-focused NGOs like the Centre for Higher Education Transformation (CHET) (CHE, 2003, Bunting and Cloete, 2004b). While CHET made a conscious attempt to develop indicators for non-quantifiable goals, such as the democratisation of higher education governance, not much attention has been paid to the incommensurable aspects of higher education (Calhoum, 2006). The necessary and unavoidable logic of policy implementation decided that institutions should concentrate on the individual components of their performance, postponing the question about the extent to which higher education institutions were being universities: were they making students think, grapple with uncertainty, understand context and question interpretations (Boulton and Lucas, 2008:30)?

Aside from the impact of the National Qualifications Framework (NQF), programme reform was not a focus of attention at national level. The concern with teaching and learning was mostly restricted to the funding of extended and foundation programmes by the Department of Education and later to the introduction of earmarked funding to develop teaching at higher education level. Community engagement, as the unfunded function of higher education, was subject to a short spurt of attention in 2005-2006 but for a variety of reasons was not followed up. No concerted and coordinated attention has been paid to this area of research - the Department of Science and Technology and organisations like the South African Academy of Science have been the most active in providing direction in this area. Here, as in relation to teaching and learning, the demands of implementation and policy choices have precluded an evaluation at system level of the ability of the South African higher education system to respond both to long-term knowledge needs and those we do not yet know exist.

Despite the pursuit of goals and objectives that characterised policy-making and implementation between 1995 and 2010, there has not been a systematic reflection on whether higher education is fulfilling its purposes. This seems to have two main explanations: on the one hand, for reasons of political accountability, the need to measure change in relation to discrete objectives, the available data and the urgency to respond to ever greater demands for higher education have all precluded a concerted and systematic reflection on the purposes of higher education from an aggregated perspective; on the other hand, the permanently delayed conversation about institutional and system differentiation and the parallel topic of each institution's fitness for purpose 
has restricted the discussion about the purposes of higher education to the quantifiable surface of the problem.

Returning to the purposes of higher education provided in the White Paper, although the least mentioned, measured and invoked the development of critical citizens entered the national consciousness in 2008 through the report of the Ministerial Committee on Transformation and Social Cohesion and the Elimination of Discrimination in Public Higher Education (Ministry of Education, 2008:89). The Committee was appointed by the minister of education in the aftermath of a particular incident of racism at the University of the Free State.

\section{The other purpose of higher education}

Of the four purposes of higher education defined in the White Paper, the socialisation of critical citizens has received the least attention at both a system and an institutional level. ${ }^{2}$ The National Plan on Higher Education (2001) left citizenship education out of the implementation equation, and none of the steering instruments - funding, planning and quality assurance focused even partially on this purpose of higher education. In the context of the simultaneous demands on higher education, access, efficiency and effectiveness may well have been regarded as preconditions for universities to start considering how to deal with this highly 'political' and less conceptualised role. Furthermore, the lack of focus on both teaching and learning and curriculum per se may have stood in the way of gaining greater understanding of what it means for universities to educate citizens.

The idea of citizenship proposed in the White Paper makes the following assumptions: that citizenship is not an automatic state or quality but rather that individuals are socialised into it; that citizenship has specific properties, ie it is critical and responsible; and that citizenship has as its purpose the reflection, evaluation and renewal of current thinking and practices and behaviour for the common good (DoE, 1997:1.3).

Despite the complexity of the ideas, it is not clear in the White Paper whether higher education is supposed to transmit a specific curricular content which will produce critical citizens as its outcome, or if there is a particular way of undertaking teaching and learning and research that will transmit citizenship values as a 'practice'. In this sense South Africa's policy framework is no different from the British one, with the Robbins (1963) and Dearing (1996) reports pointing to the transmission of standards of citizenship as one of the duties of higher education (as discussed in Ahier et al, 2003:1) and yet not specifying the manner in which this is to be done. 
Research done at British universities suggests that higher education helped students develop a sense of sociality and mutuality - that is, university life forced students to engage with one another and created the space to develop a sense of reciprocity which was focused not only on the peer group but extended to family and community and sometimes even society, broadly understood. Underlying the emergence of sociality and mutuality among university students, the authors found the principles of fairness, respect, responsibility and altruism (Ahier et al, 2003:135).

Ahier et al argue that university space structures the mode in which students socialise, but this is not solely dependent on the extra-curricular activities to which they are exposed. The authors maintain that the values, skills and qualities which emerged in the interviews they conducted with students are included in the formal procedures of academic life. The idea that citizenship, as both a socio-political identity and a set of competences, skills, values and dispositions, can surface in the act of teaching and learning is an interesting notion in the South African context and, as several chapters in this book show, could be used to add a further layer of complexity to the notion of epistemological access (Morrow, 2007; 2009). Put differently, students who cannot access the means to participate in the discourse of the disciplines offered in higher education and feel, as research has shown (Boughey, 2002; 2005; CHE, 2010), alienated from the lecturer, subject and other students, must, perforce, experience teaching and learning as non-democratic and are therefore unlikely to be taught citizenship. In 1997 the White Paper acknowledged the unfulfilled responsibility of higher education 'in helping lay the foundations of a critical civil society, with a culture of public debate and tolerance which accommodates differences and competing interests' (DoE, 1997:1.4). In all probability it is likely that the writers of the White Paper did not have the classroom experience in mind when they wrote it, and yet the diagnosis seems fitting enough to the kind of problems institutions are experiencing to a greater or lesser extent fifteen years later.

Various studies conducted before the appointment of the 2008 Ministerial Committee have provided evidence to the effect that higher education institutions were generally not being successful in creating the appropriate curricular and extra-curricular spaces to prepare students to live in a non-racist and nonsexist democratic society (CHE, 2010; HEQC Executive Summary of the institutional audits conducted between 2004-2008). The outcomes of the CHE study on institutional culture and access suggest that there was very little in the relationships among peers and between students and lecturers that could transform the classroom and the curriculum into tools for the development of 
students' socio-political identity as citizens. Many of the students and lecturers interviewed for this research at three very different South African higher education institutions gave examples of the opposite: how the tacit principles of academic scholarship generate social de-structuring and confusion among students. Misunderstanding, tacit expectations, unrealistic expectations, the lack of a common language, resentment and discomfort were among the feelings experienced by some of the lecturers and students interviewed. In many respects this demonstrates that the realisation of the responsibility of higher education in the area of citizenship cannot be separated from its ability to fulfil its role in the area of access, equity and redress.

\section{Conclusion}

The South African policy framework established purposes for higher education that were not all that different from those chosen in other higher education systems. However, the burden of the country's history gave these purposes a different sense of urgency. The need to deal with all areas of performance of higher education while simultaneously managing tensions and contradictions between them points to the difficulties with which institutions and government officials had to grapple in the formulation and implementation of higher education policy. In this context the inner workings of higher education - that is, the manner in which it dealt with curricular content and the manner of its transmission - were not the focus of systematic attention at institutions themselves and neither was this kind of reflection directly supported. Given this, it is unsurprising that the most 'symbolic' of purposes of higher education - the education for citizenship - has been seen as among the least urgent.

\section{Notes}

1 CHET has recently published three studies on universities and development from a broader perspective.

2 This does not mean that individual institutions have not focused on this issue and that citizenship has not become an area of interest among higher education researchers in South Africa.

\section{References}

Ahier, J, Beck, J and Moore, R (2003) Graduate Citizens? Issues of citizenship and higher education. London New York: RoutledgeFalmer

Altbach, P, Reisberg, L and Rumbley, L (2009) Trends in Global Higher Education: Tracking an academic revolution. A report prepared for the Unesco World Conference on Higher Education. Paris: Unesco http://unesdoc.unesco.org/images/0018/001831/183168e.pdf (accessed June 2011) Badat, S (2008) Redressing the colonial/apartheid legacy: social equity, redress and higher education admissions in democratic South Africa. Paper presented at the Conference on Affirmative Action in Higher Education in India, the United States and South Africa, New Delhi, India, 19-21 March. 
HIGHER EDUCATION FOR THE PUBLIC GOOD: VIEWS FROM THE SOUTH

Boughey, C (2002) Naming students' problems: an analysis of language-related discourses at a South African university. Teaching in Higher Education 7(3) 296-307

Boughey, C (2005) Epistemological access to the university: an alternative perspective. South African Journal of Higher Education 19 (3) 638-50

Boulton, G and Lucas, L (2008) What are universities for? League of European Research Universities, online publication. Downloaded October 2008

Bunting, I and Cloete, N (2004a) Approaches to measuring performance in higher education. A South African case study. Draft Discussion Paper, CHET website www.chet.org. Downloaded July 2011 (accessed May 2012)

Bunting, I and Cloete, N (2004b) Developing Performance Indicators for Higher Education: a South African case study. Pretoria: CHET

Calhoum, C (2006) The university and the public good. Thesis Eleven (84) 7-43

Castells, M (2001) The University System: engine of development in the new world economy. World Bank Publication. Human Info NGO Library for Education and Development Library

Cloete, N, Fennel, R, Maassen, P, Moja, T, Perold, H, and Gibbon, T (eds) (2005 second updated edition) Transformation in Higher Education: global pressures and local realities in South Africa. Ebook http://chet.org.za/books/transformation-higher-education-0 (accessed July 2011)

Cloete, $\mathrm{N}$ and Moja, T (2005) Transformation tensions in higher education: equity, efficiency and development. Social Research 72(3) 693-722

Council on Higher Education (2000) Towards a New Higher Education Landscape: meeting the equity, quality and social development imperatives of South Africa in the 21st Century. Pretoria: CHE

Council on Higher Education (2003) Towards a Framework for the Monitoring and Evaluation of South African Higher Education. Pretoria: CHE

Council on Higher Education (2004) Higher Education in the First Decade of Democracy. Pretoria: $\mathrm{CHE}$

Council on Higher Education (2009) The State of Higher Education Report. Higher Education Monitor No 8. Pretoria: CHE

Council on Higher Education (2010) Access and Throughput in South African Higher Education. Three Case Studies. Higher Education Monitor No 9. Pretoria: CHE

Dearing, R (1996) Review of Qualifications for 16-19-year-olds. Schools Curriculum, an Assessment Authority. London

Department of Education (1997) White Paper 3. A programme for the transformation of higher education. Pretoria: Government Gazette

Department of Education (2001a) National Plan for Higher Education. Pretoria

Department of Education (2001b) The Restructuring of the Higher Education System in South Africa: Report of the National Working Group to the Minister of Education. Pretoria

Hall, M, Symes, A and Luescher, T (2002) Governance in South African Higher Education. Research Report. Pretoria: CHE

Higher Education Quality Committee (2001) Founding Document. Pretoria: CHE

Jonathan, R (2001) Higher education transformation and the public good. Kagisano No 5. Pretoria: $\mathrm{CHE}$

Kraak, A and Perold, H (eds) (2003) Human Resources Development Review, 2003. Education, Employment and Skills in South Africa. HSRC Press, e-book http://www.hsrc.ac.za/Research Publication-4426.phtml. Downloaded May 2011 (accessed May 2011) 
Lange, L (2005) Higher education between the blue sea and the devil. Kagisano No 5. Pretoria: CHE

Mamdani, M (2011) The importance of research in a university. http://pambazyka.org/en/category/ features/72782. Downloaded May 2011 (accessed May 2011)

Ministerial Committee (2008) The Report of the Ministerial Committee on Transformation and Social Cohesion and the Elimination of Discrimination in Public Higher Education Institutions. Pretoria: Department of Education

Morrow, W (2007) Learning to Teach in South Africa. e-book HSRC Press

Morrow, W (2009) Bounds of Democracy. Epistemological access in South Africa. e-book HSRC Press

Motala, E (2005) Transformation Revisited. Johannesburg: CEPD

Robbins, A (1963) Higher Education. Report of the Prime Minister's Committee. London: HMSO

Scott, I, Yeld, N and Hendry, J (2007) A Case for Improving Teaching and Learning in South African Higher Education. Higher Education Monitor No 6. Pretoria: CHE

Scott, P (1995) The Meanings of Mass Higher Education. Bristol: Open University Press

Sehoole, MTC (2005) Democratizing Higher Education Policy. Constraints of reform in post-apartheid South Africa. New York: Routledge

Singh, M (1992) Transformation Time! Transformations 17 48-60

Singh, M (2001) Re-inserting the public good into higher education transformation. Kagisana No 5. Pretoria: $\mathrm{CHE}$

Trow, M (1973) The Problems in the Transition from Elite to Mass Education. Berkley: Carnegie Commission on Higher Education

Watson, D and Amoah, M (eds) (2007) The Dearing Report Ten Years On. London: Institute of Education

World Bank (2000) Higher Education in Developing Countries. Peril and Promise. Washington 